\title{
Dynamics of backyard chicken flows in traditional trade networks in Thailand
}

\author{
Beuy Joob • Viroj Wiwanitkit
}

Received: 8 April 2014 / Accepted: 30 September 2014 / Published online: 12 October 2014

(C) Springer Science+Business Media Dordrecht 2014

Sir, the recent report on "dynamics of backyard chicken flows in traditional trade networks in Thailand" is very interesting. Wiratsudakul et al. (2014, pp. 845-853) concluded that "the average distance of poultry movements ranges from 4 to $25 \mathrm{~km}$, defining a spatial scale for the risk of avian influenza that spread through traditional poultry marketing chains." In fact, to consider the dynamics of backyard chicken flow can be a good tool to monitor the tracking of avian influenza virus risk. According to the present report, Wiratsudakul et al. (2014, pp. 845-853) focused a study in one of the provinces in Thailand. There are many things to be considered. First, the pattern of backyard chicken feeding in the different provinces of Thailand is different (some provinces might have big feeding areas, away from house, and good irrigation and sanitation control system, whereas others might have crowded feeding areas, within the house, and without good sanitation control). Some provinces might have many backyard chicken feedings while the others

B. Joob $(\bowtie)$

Sanitation 1 Medical Academic Center, Bangkok, Thailand

e-mail: beuyjoob@hotmail.com

V. Wiwanitkit

Hainan Medical University, Hainan, China

V. Wiwanitkit

Faculty of Medicine, University of Nis, Nis, Serbia

V. Wiwanitkit

Joseph Ayobabalola University, Ikeji-Arakeji, Nigeria

V. Wiwanitkit

Public Health Curriculum, Surin Rajabhat University, Surin,

Thailand have only a few feedings. The movement in a limited area of $25 \mathrm{~km}$ can be seen only if there are plenty of backyard chickens. In the area with few feedings, import of backyard chicken from distant areas can be expected. In addition, there are many factors (such as local market system, rooted cultural and religious beliefs, and socioeconomic status of local population) that can affect the trading pattern in different areas. The social network analysis might be useful in clarifying the pattern in each setting (Poolkhet et al. 2013, pp. 82-86). Second, the present live poultry movements during festivals are usually moving from the standard farms to the cities. According to the previous report, "free-grazing poultry production", rather than backyard chicken feeding, seems to be related to the outbreak of avian influenza (Chantong and Kaneene 2011, pp. 596-608).

Conflict of interest None

\section{References}

Chantong, W. and Kaneene, J.B., 2011. Poultry raising systems and highly pathogenic avian influenza outbreaks in Thailand: the situation, associations, and impacts. Southeast Asian Journal of Tropical Medicine and Public Health, 42, 596-608

Poolkhet, C., Chairatanayuth, P., Thongratsakul, S., Kasemsuwan, S. and Rukkwamsuk, T., 2013. Social network analysis used to assess the relationship between the spread of avian influenza and movement patterns of backyard chickens in Ratchaburi, Thailand. Research in Veterinary Science, 95, 82-6

Wiratsudakul, A., Paul, M.C., Bicout, D.J., Tiensin, T., Triampo, W., Chalvet-Monfray, K., 2014. Modeling the dynamics of backyard chicken flows in traditional trade networks in Thailand: implications for surveillance and control of avian influenza. Tropical Animal Health and Production, 46, $845-853$ 